\title{
"I Know, But I Have No Proof". Authentic Past and Aesthetic Truth in Post-War Italy
}

\author{
Anna Lisa Tota \\ Department of Philosophy, Communication and Performing Arts, University Rome III, Rome, Italy \\ Email: annalisa.tota@uniroma3.it
}

How to cite this paper: Tota, A.L. (2017) "I Know, But I Have No Proof". Authentic Past and Aesthetic Truth in Post-War Italy. Open Journal of Social Sciences, 5, 27-49. https://doi.org/10.4236/jss.2017.512003

Received: October 21, 2017

Accepted: December 8, 2017

Published: December 11, 2017

Copyright $\odot 2017$ by author and Scientific Research Publishing Inc. This work is licensed under the Creative Commons Attribution International License (CC BY 4.0).

http://creativecommons.org/licenses/by/4.0/

\begin{abstract}
Following the perspective of cultural trauma theorists, this article focuses on the public memory of Italy's recent past, specifically the period of the so-called strategy of tension, a still very obscure time in the country's recent history and which includes the terrorist attacks that took place from 1969 to 1993 in several Italian cities. When "State Terror" occurred in Italy, access to legal and political arenas was systematically denied and the cultural trauma process could be performed only in aesthetic arenas. This article focuses on the role played by the cinema and other cultural artefacts in producing an "aesthetic truth" of Italy's recent past. By analysing the main features of the artistic and cultural representation of this past, the status of this "truth" is questioned and compared to that produced for example in the legal arena. When narrating the past, it is difficult for movies (and the same can be argued for other cultural artefacts) to achieve the quality standards of historical narration. When they narrate the past, they can remain a "second best" option. In the Italian case a very interesting trend can be noted: public knowledge of highly controversial events is often narrated using fiction. "Fiction" (more than a documentary film) seems to create the conditions that make possible the public communication of what all the citizens know but no one has proof to document. On 14 November 1974, Pier Paolo Pasolini, an Italian intellectual, published a long article under the headline "What is this coup d'état? I know" in Corriere della Sera, a leading newspaper in Italy. Probably Pasolini was murdered because of that article: he died on 2 November 1975. In that article he wrote about the strategy of tension in Italy and he said: "I know, but I have no proof". In Italy, many citizens, many intellectuals, many artists know, but they still have no proof. For this reason they can narrate the recent past of the country only by using fiction and theatrical performance. Will the aesthetisation of the recent past remain the only way to carry out the trauma process in Italian society?
\end{abstract}

\section{Keywords}

Public Memory, Cinema and Memory, Aesthetic Truth and Historical Truth, 
Terrorism, Reconciliation, Strategy of Tension in Italy

\section{Introduction}

On 14 November 1974, Pier Paolo Pasolini, an Italian filmmaker, intellectual, and poet wrote an article under the headline "What is this coup d'état? I know" in Corriere della Sera, an Italian newspaper. Probably this article is the reason why Pasolini was murdered on 2 November 1975 near Rome (Figure 1). There he wrote about the strategy of tension in Italy (1947-1993), a period characterised by several terrorist attacks (whose perpetrators still remain unknown) with many dead among civilians. Pasolini's sentence in that article "I know, but I have no proof" synthesises symbolically a specific Italian way of inscribing the recent past in the public arena. For decades it has been very difficult to recount what happened without mentioning the role of the international intelligence services (i.e. the CIA). Indeed, revealing the role of the CIA in Italy would entail ceasing to consider the USA as Italy's most important ally in the post-war period. In Italy many citizens, many intellectuals, many artists suppose what the CIA's role was in that period, but they do not yet have proof. For this reason they can narrate the country's recent past only by using fiction, theatrical performance and music. Will the aestheticising of the recent past remain the only way to "carry out the trauma process" (Alexander 2004, pp. 1) [1] in Italy? Is it also today possible for Italian civil society to claim to know the truth on the historical level? Especially in the international debate there seems to be a persisting gap in relation to Italian terrorism during "the years of lead" between the public memories of the left-wing terrorism (due to the Red Brigades) and the right-wing terrorism (due to fascist groups, such as Ordine Nuovo). While the left-wing terrorism has been extensively inscribed in the Italian and in the international public discourse,

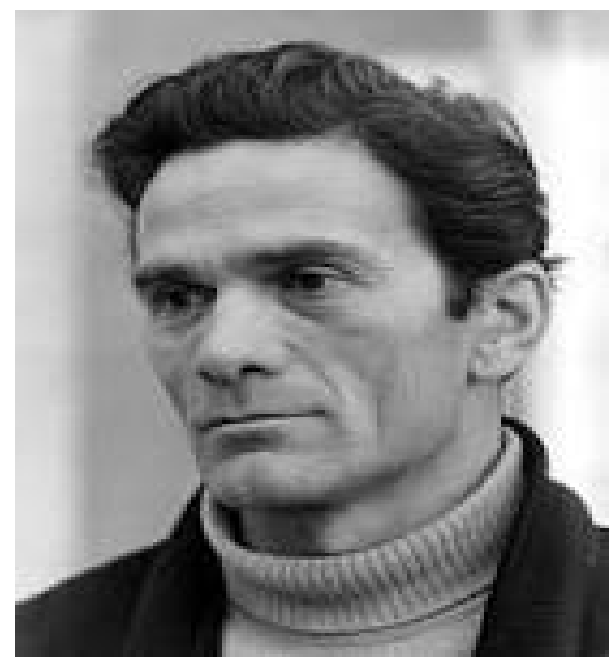

Figure 1. Pier Paolo Pasolini (Bologna March 5, 1922; Ostia November 2, 1975). 
some of the right-wing terrorist attacks in many cases not yet (Tota, 2003 [2]; Tota, 2005a [3]). For example, the terrorist attack on Train 904 (23 dicembre 1984) in Val di Sambro has been almost totally forgotten, even if it happened only three decades ago, due to the very active and efficient cultural amnesia instigated by some camorra's clans (Tota, 2005b) [4]. Nowadays the public oblivion in relation to this terrorist attack still persists.

During the strategy of tension period the attacks on banks (Milan 1969), railway stations (Bologna 1980), piazzas (Brescia 1974), trains (Italicus, 1974; Train $904,1984)$ were mainly due to the right-wing terrorism and the legal arena has not functioned mainly in those cases. This is the more controversial part of the recent Italian past and it has not be confused with the left-wing terrorism that had very different characteristics (instead of bombs located in public spaces for mass murdering, the killing of political or institutional actors considered as state symbols). Aldo Moro in 1978 was the most famous victim of the Red Brigades, but from 1974 to 2003 their victims are estimated to be 84 . The link between the deviant part of the Italian intelligence services and the American ones could never been proved, but many Italian citizens believe, as Pasolini did, that the right-wing terrorist attacks were somehow connected to the international organization called "Gladio" and to the American intelligence services. According to this point of view the right-wing terrorist attacks in Italy should be reconsidered in the broader international scenario of the Cold War. The reasons why at the national level justice was and still is not possible would not depend just on the Italian corruption and the limited maturity of the Italian democratic state, but also on the persisting limited sovereignty of the state on its own territory after the defeat of the Second World War. The interlink between the deviant part of the Italian intelligence services and the American ones would highlight in a very different way all the "conspiracies" that characterize Italian recent past. In other terms, in Italy legitimate claims of obtaining justice in relation to the right-wing terrorist attacks in "the years of lead" could not be articulated on the national level, because there were interfering obstacles due to the international level. Why in relation to Italy there is this recurrent narrative of "conspiracy"? Can one explain it just in terms of the Italian imagination or are there any more fundamental reasons why to obtain justice was in some cases almost impossible? ${ }^{1}$

This article deals with the impossibility, and/or at least the difficulties, of rendering this recent and controversial past in the historical realm, especially that related to the right-wing terrorist attacks. It hypothesises that in Italy the aestheticising of this past has functioned as a "second best" solution to inscribe the Italian past in the public discourse without provoking the radical change in Italy's international relations, which would have been unavoidable if the historical truth had been revealed. It will be argued that Italian society would have run the ${ }^{1}$ Very interesting arguments in relation to the "conspirancy" narrative are raised by Antonello (2012) [43] in relation to Pasolini's status as martyr and his impact on the left in Italy and also by Gordon (2007) [44]. 
risk of a civil war, of the breakdown of the newly constituted democracy, if the role of the American intelligence services in the Italian context of those years had been denounced in the form of historical truth and inscribed as such in the national and international public discourse.

After the end of the Second World War there began a long period during which Italy was under the control of the nations that had won the war, especially the USA. Even if historians do not fully agree, the dates usually cited as marking the duration of the Cold War are 1947 to $1993^{2}$, a very long period of time indeed, and during which Italy was positioned exactly on the border between the American area of influence and that of the Soviet Union. It was a complex historical period and to some extent still obscure in many of its events. Italy was often described as a country with "limited sovereignty" and as an "American colony", especially during the "strategy of tension" period (1947-1993). From a sociological perspective, it can be argued that the strategy of tension was entirely inscribed neither in the national public discourse nor in the international one. The role of artistic codes (especially that of the cinema) was necessarily amplified by the difficulties of legitimising a shared version of what happened during those years. The terrorist attacks were so frequent and caused so many deaths among civilians that what happened in Italy cannot be compared with events in any other European country. This is not to suggest that the only possible account of that period has been offered in Italy through the arts (and specifically through the visual and performing arts). Since 1976 many sociologists and historians have written articles and books on post-war Italy (Wagner-Pacifici, 1986 [5]; Dicky, Foot, Snowden, 2002 [6]; Tranfaglia, 2010 [7]; Tranfaglia, 2011a [8]; Tranfaglia, 2011b [9]; Galfré, 2014 [10]). However, the strategy of tension period has not yet been fully rendered in the public discourse, especially the right-wing terrorist attacks in which the role of the national and international intelligence services has been suspected. Documented in what follows is the extent to which the aesthetic shape of this past has prevailed as the main form of public memory. In section 1 of this article I will acknowledge the impossibility of any full reconstruction of a historical event, and I will consider the different forms of authenticity of the past, with regard to either the historical realm (historical truth) or the artistic and cultural ones (aesthetic truth). Moreover, by applying the cultural trauma model (Alexander et al., 2004) [11] to the Italian case I will illustrate how and to what extent aesthetic truth has functioned as a "second best" solution. In Section 3 I will briefly explain the period of the strategy of tension in Italy. In Section 4 I will document the fundamental role played by the cinema in the process of aestheticising the public memory of the strategy of tension, and I will analyse a specific movie. Finally in the conclusion (Section 5) I will argue that "the authentic past" does not exist per se, because an authentic depiction of the past is not entirely possible. The social construction of authenticity and its different forms of mediation can be considered in relation to the historical truth. ${ }^{2}$ On $27^{\text {th }}$ July 1993 a terrorist attack took place in via Palestro in the centre of Milan. This is considered the last event connected with the strategy of tension in Italy. 
However, framed as such, the authentic past is better understood in relation to its capacity to make aesthetic and artistic paths to justice possible, and to provide modes of obtaining knowledge about the past impossible to access otherwise, exactly as happened in the case of the filmic narration of the strategy of tension in Italy. As we will see, a movie like "Piazza Fontana: The Italian Conspiracy" by Marco Tullio Giordana (2012) has contributed to constructing a historical world that has made possible new public knowledge of both this terrorist attack and the whole period of the strategy of tension.

The main concern of this article is to highlight the ways in which the public memories of the strategy of tension have been constructed through different cultural artefacts. In the case here considered the role of the cinema prevails; however from a sociological perspective the specific shapes of public memories can never be reduced just to a unique form of cultural representation. For example, as we will see, in the case of Piazza Fontana the public memories of that case are related and shaped through Giordana's movie such as through Baj's painting. In this sense to reduce the analysis to the filmic codes would undermine the relevance and the adequacy of the whole analysis. It is exactly in the interplay between different artistic codes that one can see the emergence of the specific shape of this memory.

\section{Historical Truth and Aesthetic Truth: The Authenticity of the Past}

The strategy of tension period is a very difficult and contested one. There were so many mysteries and intrigues to make it suitable for the plot of an action movie. However, independent from the opacities of this specific case, a more general issue should be considered: it concerns the ontological possibility of fully comprehending a historical event. In other words, is any "authentic" past possible? Can one fully comprehend an event? If part of the impossibility of inscribing the strategy of tension in the Italian public discourse is certainly due to the specificities of this case (as will be shown in Section 3), another part of it is due to a more general question that arises in every process of representation. When one recalls the past, its depiction can never be entire. Even the historical truth can be considered a contingent construct depending upon different perspectives and more or less "politicized" points of view. This is not to dissolve the past and its consistency into a polyhedral myriad of contrasting and antagonistic versions that concur in the public sphere and are meant to be equally possible. The main concern is to problematize any remaining granitic solidity related to the so-called historical truth that has more to do with characteristics of the scientific discourse than with the realm of reality. The core issue is the ontological problem implicit in the relation among a depiction, a specific narration and the reality depicted. It is impossible to comprehend an event fully. The reality exceeds any attempt to represent it entirely ${ }^{3}$.

${ }^{3}$ A very important contribution to this debate is due to Hayden White (1973) [45], who claimed that much of history writing is a fiction, because it imposes a narrative on events that no longer occur. 
A theoretical framework for the analysis of the restless nature of historical events is offered by Wagner-Pacifici in her analysis of the exemplary case of September 11 (Wagner-Pacifici, 2010) [12]. The author argues that the concept of event must be removed from its narrow historical frame. She thus proposes a methodology able to capture the intrinsic restless nature of events, claiming that any historical account of an event can only be partial. In a more recent contribution Wagner-Pacifici calls "for a quantum sociology of events, analogous to quantum mechanics in physics. (...). For analytical purposes, such an analogous approach to events would allow us to grasp events in their movements and trajectories and in their stabilizations in forms and objects: movement and stability; particle and wave; continuities and discontinuities; form and flow" (Wagner-Pacifici, 2016, p. 23) [13].

In addition Jeffrey Olick (2014) [14], going back to the original idea of Halbwachs (1950) [15], has proposed to consider memory as a dynamic process, exactly in the attempt to capture the instability of any representation. A historical event cannot be frozen and immobilized forever in one unique representation. Its meanings and nature will change over time. This analytical framework which takes into account, and builds on, the understanding of events is also applied to the filmic shapes of the past here considered.

The historical truth, framed as such, corresponds to a representation of the past that it is constructed according to the scientific rules and conventions established in the historical realm. Rubin (2002, p. 81) [16], for example, in illustrating the aim of cultural history, states that access to the past is mediated through "the informed subjectivity, human and intellectual capacities for categorization, system-building and empathy" and the "wishes, pain, hope and desire" that the historian brings to the past. Moreover, if we switch from the historical realm to that of memory studies, statements about the constructive nature of any process of remembrance and/or narration of the past become even more radical (Tota and Hagen, 2016) [17]. If one considers the current debate on memory studies (Olick, Vinitzky-Seroussi and Levy, 2011) [18], concerns about the authenticity of the past can be framed in terms of the past's structure of plausibility. In other words, as different versions of a contested past compete with each other in the public arena, they contribute to shaping and reshaping the contents to be remembered. In contemporary societies, public knowledge related to a certain past or the ways in which a trauma has been inscribed in the public discourse depends not only on the historical work written on that event, but also on different cultural artefacts produced in relation to that past. Besides the historical truth, we are witnessing the emergence and spread of many different forms of aesthetic truth conveyed via artistic and cultural artefacts (movies, exhibitions, theatrical performances, songs). Memory work seems to function nowadays, probably more than in the past, through aesthetic codes. However, questions related to the kinds of knowledge of which art is capable are certainly not new and can be related back to Book X of Plato's Republic. As Dorter, commenting on Plato, argues: "We can see that the aesthetic experience of art is able to convey a 
non-conceptual kind of truth about our emotional life insofar as the experience with which it presents us 'rings true' emotionally." (Dorter, 1990, p. 38) [19].

In a following part of the same text Dorter (1990, p. 45) argues: 'moral truth can be intrinsically reflected in aesthetic thinking', because both morality and beauty imply the "suspensions of self-centered instrumental value in favour of intrinsic value. (...) The aesthetic experience as well removes us from the realm of desire and elevates us above our private concerns to an experience felt as valuable in itself."

It is no coincidence that in the case of strongly contested and controversial pasts, aesthetic codes can address that which one cannot directly address: the unspoken, the invisible, what the victims never had the chance to reveal. Aesthetic experience seems intrinsically to share something with morality ( $\kappa a \lambda \dot{\alpha}$ $\kappa \alpha i \dot{a} \gamma \alpha \theta \dot{c} \varsigma$ ), as the ancient Greeks said. Aesthetic codes seem to function as privileged means to devise unusual and unpredictable paths to justice, to recount what the silent voices of the past were unable to say, to recall the invisible presences of the victims who were not allowed to say what really happened to them... In this sense aesthetic languages contribute to opening memory for us, articulating dilemmas that otherwise could not be considered. The arts make possible the experience of an empty space and place where the invisible can be seen, where the unspoken can be said, where the victims can be finally heard. The channels of this experience are less cognitive than emotional. As Dorter recalls, it is precisely the fact that the emotions felt in relation to a certain past are shared among the receivers of a specific artwork (or a movie, a song) that disclose to them the possibility of acquiring new knowledge of that past which would not be possible otherwise. The aesthetic experience can contribute to creating a context favourable to moral thinking in relation to public events. It is for this reason that arts and justice are very often linked together.

Thoughts of this kind have been further developed in the sociological debate on public memory, especially in its cultural wave. Wagner-Pacifici and Schwartz (1991) [20] theorised the notion of "genres of memory" to investigate further the relation between aesthetic forms and contents of collective memories. In 1996 Wagner-Pacifici wrote: "Memories are never formless (...). The fact of embodiment in form is what all collectives memories share" (1996, p. 302) [21]. Wagner-Pacifici's article and the previous study on the Vietnam Veterans' Memorial by Schwartz and Wagner-Pacifici (1991) provided the theoretical and empirical basis for a "genre of memorization". Today the implications of this genre still warrant further investigation. The implied idea is that the medium of narration deeply and/or partially affects the content to be narrated. In other words, it is argued that insofar as the form shapes the content, the content itself may change. Some years later, and adopting a slightly different perspective, cultural trauma theorists (Eyerman, 2002) [22] argued that public knowledge about controversial events-such as terrorist attacks, wars, mass murders and/or systematic violations of human rights-can be shaped through different codes. According to Alexander (2012) [23], there is a gap between an event and its public 
representation: a trauma does not have a meaning in itself. It is necessary to elaborate one or several individual and social meanings of it. The trauma process consists precisely in dealing with this gap. Moreover, the process of socially constructing the different meanings of a traumatic event can be carried out in different arenas, such as the legal, scientific, and aesthetic ones (to mention just some of them). When in a national context, one of these arenas for some reason does not function (for example, because of successful pressure by a criminal organization, such as the Mafia or Camorra, on the legal system), the trauma process-i.e. the process of elaborating the trauma and inscribing it in the national public discourse-can and must be carried out in other arenas. If it is not, cultural amnesia will probably occur. This means that the traumatic event considered will not be inscribed in the public discourse and will probably remain a "latent and silent presence" in the collective unconsciousness of that collectivity. If one applies Alexander's model to the Italian case, it emerges that the period of the "strategy of tension" has not yet been inscribed in the Italian public discourse. This absence depends on different forms of instigated amnesia. During the strategy of tension in Italy, access to political and legal arenas was systematically denied. Therefore the cultural trauma process could be worked through only in aesthetic arenas that-as said-can function as privileged terrain for the emergence of morality related to public issues, such as a society's contested pasts and cultural traumas ${ }^{4}$. In Italy, many different aesthetic codes have been successfully used to perform the trauma processes related to the "strategy of tension" (theatre, literature, photography, music, graphic novels). Also these "aesthetic truths" are partial reconstructions of what happened and do not claim to make full understanding of that period possible. On the contrary, the main characteristic of opening public memory through arts consists in the fact that aesthetic codes shape memories in autonomous ways that cannot be reduced to any unique political interpretation of a contested past. As Goldfarb (2016) [24] argues, arts are independent. They therefore do not pretend to "resolve" any dilemmas and/or conflicts emerging from a certain past. Arts simply contribute to making these dilemmas visible by letting them speak to the society. By so doing, they help articulate these dilemmas in ways that can enrich the democratic life of a society:

"Art does not only open up ways to see how memory and forgetting work differently among groups that share much in common, but also much that is not in common. Art informs memory beyond clichés. It opens us to the social condition of memory, not providing easy lessons, but questions, alternative understanding and commitments. (...) It also opens up the possibility of a more democratic political life, confronting the social condition of memory of difficult pasts in ways that make it less likely that the pasts will repeat themselves" (Goldfarb, 2016, p. 124).

The role played by the cinema in "working through" the Italian Terrorism has

${ }^{4}$ See also Antonello and O'Leary (2009) [46], who consider the role and the function of Italian cinema and the media in the so-called "years of lead" (anni di piombo) in Italy between 1969 and 1980. 
been analysed in film studies by several scholars (O'Leary, 2011 [25]; (Glynn, Lombardi, O'Leary, 2012 [26]; Hayek, 2013 [27]). It has been argued that in the absence of a truth and in the impossibility of having justice (for example, through reconciliation commissions dealing with the crimes perpetrated during the strategy of tension, Italian cinema might have been performing an analogous function (Antonello, O’Leary, 2009) [28]. As O’Leary (2010, p. 244) [29] argues: "Italian cinema has played a prominent role in articulating the ongoing impact of the anni di piombo and in definining the ways in which Italians remember and work through the events of the long 1970s."

These contributions have been central to highlight the role of the cinema in shaping Italian public knowledge and public memories of this past. However, the role played by the associations of victims' relatives in producing the public narratives related to some of these events has not to be underestimated. There is a persisting lack in Italy of researches on this period able to connect empirical data related on commemorative ceremonies and on public activities of the victims' relatives associations and the different forms of cultural artefacts (movies, theatrical performances, songs) that shape the public memory of a specific event. The trauma theories here considered can help to better understand how these public memories were and still are effectively constructed: exactly in the interplay between cultural artefacts and social practices. From a sociological point of view, it has no sense to limit the analysis just to the cinema. If in the construction of the public memories of a certain event more and different cultural artefacts have played and are still playing a relevant role, they have to be considered jointly. To limit the analysis to the movies might introduce a bias in the analysis. In this contribution, even if it has as main focus the role played by the cinema in the reconstruction of the public knowledge of these years, the main focus remains related to public memories. Therefore, for example, the intertwined role played by a painting ("The Pinelli's funerals" by Enrico Baj) and the movie by Marco Tullio Giordana will be analysed. The next section briefly considers what happened during the strategy of tension in Italy.

\section{The Strategy of Tension in Post-War Italy}

On 14 November 1974 Pier Paolo Pasolini published in Corriere della Sera an article entitled 'What is this coupe d'état? I know' which-as said-was considered his death sentence. After Pasolini's murder, Giuseppe Pelosi, a seventeen-year-old hustler, was arrested. He confessed to Pasolini's murder. On May 7, 2005 Pelosi retracted his confession, which he said was made under the threat of violence to his family ${ }^{5}$.

This is the part of Pasolini's article where he mentions some of the main important terrorist attacks in post-war Italy and the role of the American intelligence services in the Italian "strategy of tension":

"I know. I know the names of those responsible for what has been called a ${ }^{5}$ For sections 3 and $4 \mathrm{cf}$. Luchetti and Tota (2016) [47]. 
coup (and what was in fact a series of coups committed as a power protection system). I know the names of those responsible for the bloodbath of Milan on 12 December 1969. I know the names of those responsible for the atrocities of Brescia and Bologna in the early months of 1974. I know the names of the group of powerful people who, thanks to the CIA's help (...) first created (though failing miserably) an anti-Communist crusade, (...) and later, again with the help and inspiration of the CIA, recovered a fascist virginity to reverse the disaster of the "referendum" (...). I know the names of those who, between one church mass and another, gave orders to, and guaranteed the political protection of, old generals (kept in reserve ready for a coup d'état), of young neo-fascists, or rather neo-nazis (to create a real base of anti-Communist tension) and lastly of common criminals (...). I know all the names and I know of what they are guilty (attacks on institutions and public bloodbaths). I know. But I have no proof. I have no evidence. Probably-if American power will allow it-maybe deciding "diplomatically" to grant to another democracy the same that American democracy has granted concerning Nixon-sooner or later these names will be revealed. I know because I am an intellectual, a writer who tries to follow what is happening, to read everything that is written, to imagine things that nobody admits to knowing or things that are left unsaid. I link distant facts, I put together the shattered and scrambled pieces of a whole, coherent political picture that restores logic to where arbitrariness, madness and mystery seem to reign. (...) After all, it is not that difficult to reconstruct the truth about what has been happening in Italy since 1968..." (Pier Paolo Pasolini, "What is this coup d'état? I know," Corriere della Sera, 14 November 1974) [30].

During the trial for Pasolini's murder, Guido Calvi, the prosecutor, said:

"Why did Pasolini die? Indeed, one does not need to be an intellectual or a storyteller to acquire the awareness that drove Pasolini's pen that day. Millions of Italians 'know', and every day in city squares, factories, schools, everywhere, they express their dissent, fruit of their knowledge. In the same way, we know who were the real instigators and the 'ideal' perpetrators of Pasolini's murder, as they stand behind the scenes of this apologue. And the crowd of Romans full of anguish and rage who came to say their last goodbye in Campo de'Fiori, they knew. That crowd, so heterogeneous, so 'Roman' so popular and therefore so 'unreliable', knew and they know. But like us, they have no proof. Only a few clues. (part of Guido Calvi's speech to the court during the trial on 24 April 1976, published in http://www.pasolini.net)".

Many Italian intellectuals, artists, scientists, like many citizens, believe that Pier Paolo Pasolini was murdered because of the truth revealed in that article, a truth that should not have been written. The "crime" committed by the famous Italian poet and filmmaker was to write the unspoken, to reveal the invisible to Italian citizens, and by doing so to awaken the Italians' political and historical conscience. In other words, his crime was to be an intellectual and to exercise his power to change common and deep-rooted beliefs. His "crime" was to help ordinary people to understand what was going on in Italy during those years, why 
there were so many terrorist attacks, why so many children, women, and civilians had to die for no apparent reason.

A similar claim about the possibility of thinking in the face of injustice was made by Hannah Arendt (1963) [31] in Eichmann in Jerusalem: following Arendt, we can say that not only did Pasolini reveal what people knew, but he argued that knowledge needs no proof but thinking and making connections. Moreover, the danger he posed is that he was practically raising political awareness toward political action and change. The comparison between Arendt's and Pasolini's thoughts is fascinating. There are many points of intersection between their concepts of revolution, political action, and civil disobedience. Both Arendt and Pasolini show profound interest in various forms of political actions that "are potential sources for the re-enabling of political legitimacy and public freedom" (Rensmann, 2015, p. 300) [32]. As Sergio Benvenuti pointed out in a conference on psychoanalysis held some years ago, "while Hannah Arendt's work deals with the banality of evil, Pasolini's work deals with the banality of good". Pasolini's style is to provoke, to disrupt with his words the banality of everyday thoughts and routines, to awake Italian citizens who seem to be falling asleep in the face of random cruelty and injustice and to have lost their capability of understanding what's going on in the Italian politics and society. In the article published on the Corriere della Sera he calls, at risk to his own life, for public awareness about the "strategy of tension" that occurred in Italy at that time.

What is the "strategy of tension"? Historians use this expression to refer to a specific period of recent Italian history from 1947 to 1993 . There are different opinions as to the date of its beginning: according to the British weekly, The Observer, which first coined the expression, it started with the Piazza Fontana bombing in the center of Milan (12 December 1969). However, some scholars ${ }^{6}$ date its beginning to the massacre of Portella della Ginestra on 1 May 1947, which has been considered "the first State slaughter". The Portella della Ginestra massacre was a very violent act in Italy's recent history: eleven people were killed and twenty-seven wounded during May Day celebrations in Piana degli Albanesi in Sicily. The bandit Salvatore Giuliano and his band were held responsible. However, the effective perpetrators and the reasons for the massacre (which are still a matter of controversy) have to do with the conservative forces, who wanted to prevent the Sicilian labourers from obtaining their rights against the landowners. In other words, it was the first successful attempt to prevent communist ideas from spreading among Sicilian farmers and labourers. Among the victims there was a child named Vincenza La Fata, who was only eight years old. The expression "strategy of tension" refers to a subversive strategy adopted by ${ }^{6}$ Many scholars maintained that the slaughter in Portella della Ginestra constitutes the beginning of the strategy of tension in Italy. See for example the important contribution by Ferdinando Imposimato (2012) [48], but also the official report of the "Commissione parlamentare sul terrorismo in Italia e sulle cause della mancata individuazione dei responsabili delle stragi" (1997), in which even the title of the first volume points "Portella della Ginestra" as the beginning of this obscure period ("L'Italia delle stragi: Da Portella della Ginestra alla strategia della tensione nella relazione della Commissione Stragi”). 
part of the State and based on terrorism in order to create tension and fear in the population such to justify the return to an authoritarian state. It was aimed to avoid the prevalence of leftist forces close to the Communist Party in the newly constituted democratic state. The bomb that exploded in Piazza Fontana (1969) in the center of Milan was the response of some of the most reactionary forces of Italian society (the neo-fascist groups, but probably deviant groups of the state security apparatus with complicity and international ties to the international intelligence services) to the strong wave of social struggles in 1968-69 and to the election of the Italian Communist Party. The weapon of mass murderer was again used:

a) in 1970 (the terrorist attack of Gioia Tauro on July 22);

b) in 1973 (the terrorist attack on the police headquarters in Milan);

c) in 1974, after the liberal victory in the referendum on divorce (the terrorist attack of Piazza della Loggia in Brescia on May 28 and the terrorist attack on the Italicus train in Val di Sambro on August 4);

d) in 1980 (Bologna railway station massacre on August 2);

e) in 1984 (the terrorist attack on Train 904 once again in Val di Sambro on 23 December).

These terrorist attacks are only some of those that occurred during those years, and they were not the only expression of the strategy of tension. Organised in the same period was the systematic infiltration of the mass movements and extra-parliamentary organisations, including those of the left, in order to raise the level of conflict. There were probably connections (never documented) with international organisations in Europe (such as the Gladio system). It was also the period of the threat of coups: the plot of 1964, the Borghese coup attempt of 1970. As said, the history of that period is so replete with mysteries and intrigues that it would be perfect subject matter for a new James Bond series. It is certainly no coincidence that the impossibility of recounting this past on the historical level has been somehow faced through the aesthetic codes offered by the cinema. In their book on the Bologna terrorist attack, Boschetti and Ciammitti (2010) [33] argue that during the strategy of tension the Nuclei Armati Rivoluzionari, a neo-fascist terroristic group was the linkage among the CIA, the deviant part of Italian intelligence services, and a group of Italian politicians who wanted right-wing parties to prevail in Italy, even through a coup. Daniele Ganser (2005) [34], a Swiss historian, has studied the role of a 'stay-behind' paramilitary organization (called "Gladio") with the official task of countering a possible Soviet invasion of Europe during the cold war. This organization had to prevent by any means communist parties from coming to power in Western Europe. Ganser argued that Allen Dulles, CIA director, was one of the key actors of Gladio. In Italy, on 24 October 1980 Giulio Andreotti, an Italian politician of the Christian Democracy party who died in 2013, revealed the existence of Gladio and its role in Europe. Andreotti was Prime Minister for seven times and also during Aldo Moro's kidnapping and assassination by the Red Brigades in 1978. He defined Gladio as a structure of defense, information and safety. A film 
has been devoted to his highly controversial life: "II Divo" (2008) directed by Paolo Sorrentino. It documents Andreotti's strong influence on Italy's recent past. However, also William Colby, CIA director from 1973 to 1975, wrote about the existence of Gladio in a book dedicated to his life in the CIA (Colby and Forbath, 1978) [35]. This is the international context that can frame the terrorist attacks in Italy from 1947 until 1993. There is no direct proof, but several clues make the hypothesis of CIA's involvement plausible.

This entire period remains relatively unknown to the rest of the world, not to mention its obscurity in the collective consciousness of Italian citizens. It is an 'unaccomplished memory' in the sense that it could never be inscribed in public debate because of the public's lack of awareness of a large part of these terrorist actions. As said, the hypothesis, often propounded but never proven, is that the strategy of tension was made possible in Italy by collusion between the deviant part of the Italian state intelligence services and the activities of the international intelligence services, especially the CIA. Without direct understanding of the role played by the CIA, and perhaps also by other international intelligence services cooperating with the United States, it is impossible for this public memory to accomplish its complete form. It is not just a matter of elaborating what happened at the public level. It is a matter of granting the Italian nation and to its citizens the right to properly "label", or to name, what happened, and therefore subsequently the right to forget.

There is also an extract from the report of the Red Brigades on their interrogations of Aldo Moro ${ }^{7}$ during his imprisonment, in which he underlines the role of associate countries in the strategy of tension:

"The so-called strategy of tension had the purpose, although fortunately not attained, to restore Italy to normality after the events of 1968 and the so-called 'hot autumn'. It can be assumed that the associated countries [which were] interested in various ways in our policy and therefore interested in sponsoring a certain politics were somehow involved through their [intelligence] services." (Commissione Stragi, Memoriale Aldo Moro, 2: p. 360) [36].

The next section focuses specifically on the role played by the cinema in producing "aesthetic truths" concerning the strategy of tension.

\section{Cinema and History: The Aestheticising of the Public Memory in Italy}

There is ongoing and lively debate on the relation between history and cinema (Rosenstone, 2014) [36] that cannot be summarized in a few lines ${ }^{8}$. Rosenstone (1995, p.5) [37] argues:

"Let's face the facts and admit it: historical films trouble and disturb (most)

\footnotetext{
${ }^{7}$ Aldo Moro, Prime Minister of Italy from 1963 to 1968, was kidnapped by the Red Brigades on 16 March 1978 and murdered after 55 days of captivity. For an analysis of the Moro's case see Wagner-Pacifici (1986).

${ }^{8}$ It is not meant here to reduce the aestheticizing of the Italian public memory to its filmic form. Many other aesthetic forms of this past can be considered. In this article I have decided to focus mainly on the role played by the cinema.
} 
professional historians. Why? We all know the obvious answers. Because, historians will say, films are inaccurate. They distort the past. They fictionalize, trivialize, and romanticize important people, events, and movements. They falsify History. As a subtext to these overt answers, we can hear some different, unspoken answers. Film is out of the control of historians. Film shows that academics do not own the past. Film creates a historical world with which the written word cannot compete, at least for popularity. Film is a disturbing symbol of an increasingly post-literate world (in which people can read but won' t)."

As a matter of fact, in contemporary societies besides the historical means of producing the past, other means of cultural production have emerged: cinema, television, websites. This tendency is neither new nor original. For many centuries, literature has competed with history in the representation of the past. So why are some contemporary historians so concerned about this new trend? The difference lies in the capacity of the different media to affect and influence public opinion. There are only a very few literary works that become famous worldwide, but an ordinary film can reach thousands of people in a few weeks. By analysing the main features of the filmic representation of the past, the status of this "aesthetic truth" has been questioned. When narrating the past, it is impossible for movies to achieve the quality standards of historical narration. While they narrate the past, they can remain a "second best" option. Obviously, these remarks must be framed within a more general reflection on filmic genres: a documentary film differs radically from a fiction film. In the Italian case, a very interesting trend can be noted: the public knowledge of highly controversial events is often narrated by using a fiction film. A "fiction" (more than a documentary film) seems to create the conditions that enable the public communication of what all citizens know but no one has the proof to document: 'I know, but I have no proof, to quote Pier Paolo Pasolini again. The Italian case is a very good example of the "new kind of history" proposed by Rosenstone (1995, p. 21) [37]:

"To take history on film seriously is to accept the notion that the empirical is but one way of thinking about the meaning of the past. Accepting the changes in history that mainstream film proposes is not to collapse all standards of historical truth, but to accept another way of understanding our relationship to the past (...). Film neither replaces written history nor supplements it. Film stands adjacent to written history (...)."

Rosenstone is right to propose a comparison between the past as constructed by movies and history as told by bards. It is not my intention here to further develop the debate on the relation among history, films and public memory (Tota, 2010) [38]. However, it is important to recall the legitimacy of the filmic narration of the past because it is a key argument in this study.

The following part of this section considers a specific case related to the main hypothesis of this article: the aestheticizing of public memory in Italy.

"Romanzo di una strage" is a 2012 Italian drama film directed by Marco Tullio Giordana, who is a very well-known director and scriptwriter from Milan. The film is based on a book written by Lorenzo Cucchiarelli "The mystery of Piazza 
Fontana". It deals with reconstruction of the terrorist attack that took place in Milan on 12 December 1969 in the centre of the city. The film was released internationally as "Piazza Fontana: An Italian conspiracy". This title is particularly surprising because the film clearly and very courageously suggests a relationship among NATO, international intelligence services, Italian ones and the NAR (Nuclei Armati Rivoluzionari). Therefore a more adequate title for the international market would have been 'Piazza Fontana: An international conspiracy'. The film recalls what happened on 12 December 1969 in the National Bank of Agriculture in Milan. ${ }^{9}$ The bank is located in Piazza Fontana in the city centre, a small square just behind the city's cathedral. On 12 December 1969 at 4:37 pm, an explosion in the bank's hall killed seventeen men, fourteen upon impact. The blast additionally injured 88, including 33 employees of the bank. The victims were in the bank for the agricultural market held on Fridays after normal business hours. The blast was a tragedy that struck the nation, in part because of the socio-demographic profile of the bank's customers on that particular afternoon: a bomb seemingly placed at random but appearing as a symbolic assault on the working class employed in the agricultural sector.

A few minutes before the explosion at the National Bank of Agriculture, a second bomb was found undetonated in the headquarters of the Italian Commercial Bank, in Piazza della Scala, again in the center of Milan. On the same afternoon, additional explosions occurred in Rome: one at the National Bank of Labour and two in front of a famous Italian monument, "Altar of the Fatherland" (Altare della Patria) in Piazza Venezia, with about twenty wounded. In total, five terrorist attacks concentrated within just 53 minutes occurred simultaneously in Italy's two largest cities. Thus began the so-called "strategy of tension", even if as already mentioned some Italian historians consider the attack in Portella della Ginestra to be its actual beginning. The victims' funerals were held at the cathedral of Milan on 15 December 1969: 300,000 people gathered in the cathedral square. There were no flags, no party symbols. But the story was just at its beginning. Three days later, on 15 December 1969, Giuseppe Pinelli died: he was an anarchist railway worker taken to the police station by the police inspector Luigi Calabresi on the evening of the massacre together with other left-wing activists. After Pinelli had been questioned continuously for three days, he "fell" from the window of Calabresi's office on the fourth floor. The police's official version was that Pinelli had committed suicide. Police commissioner Marcello Guida told a press conference that Pinelli's action was a voluntary act resulting from the collapse of his alibi and thus, indirectly, evidence of his involvement in the massacre. Most newspapers complied with the police version. The headlines read: "Dramatic turn of events: suspect kills himself in police station", Corriere della Sera, 16 December 1969, "Dramatic fall from the fourth floor of the police headquarters by railway anarchist", Il Gazzettino, 16 December 1969; "Pinelli was a leading suspect", Il Giorno, 16 December 1969. Yet some courageous reporters began to organise counter-information: Lotta Continua, an ex${ }^{9}$ For the analysis of the Piazza Fontana case see Foot (2009) [49] and Luchetti (2013) [50]. 
tra-parliamentary left-wing Italian movement, launched an aggressive campaign in its weekly magazine to prove the inconsistencies in the police version and undermine the credibility of the police, especially police inspector Luigi Calabresi, who always claimed that he had not been in the room at the moment of Pinelli's death. In 1970 Calabresi brought legal action against the editor-in-chief of the Lotta Continua newspaper, while Pinelli's wife and mother, in 1971, brought suit against Calabresi and the police present during the questioning for voluntary manslaughter, kidnapping, private violence, abuse of office and abuse of authority. Luigi Calabresi, however, did not see the end of the process because he was murdered outside his home on 17 May 1972 with two gunshots. ${ }^{10}$ The trial, presided over by judge D'Ambrosio, ended in 1975 with not guilty verdicts for all the defendants on the basis of "lack of evidence".

Some fundamental factual truths about the bombing in Milan are agreed upon, but it remains a very controversial past. It is replete with dilemmas that have divided the city of Milan and the whole nation for decades. This is the reason why the film by Marco Tullio Giordana has played such an important role in illuminating some of these dilemmas without attempting to resolve any of them.

The main dilemmas of this past concern:

a) The attribution of responsibility (who were the perpetrators) of the Piazza Fontana bombing (first attributed to the anarchists, then to a neo-fascist group of terrorists-the so-called "Italian black terrorists" opposed to the "Red Brigades" more linked to the left extra-parliamentary organizations-and finally to the neo-fascists connected with deviant parts of Italian and international intelligence services).

b) The death/murder of the anarchist Giuseppe Pinelli at the police headquarters in Milan, three days after the Piazza Fontana bombing.

Both of them represent highly politicized dilemmas, as they clearly articulate the political opposition between left and right in their more extreme variants. To provide an example of the depth of these divisions and to suggest the extent to which these divisions were rooted in Milanese society, let us consider the following photograph, which depicts a culminating point in the reconciliation process. On 9 May 2009, during the Commemorating Day of the Victims of Terrorism, Licia Rognini, Giuseppe Pinelli's widow, and Gemma Capra, the widow of the policeman Luigi Calabresi, met for the first time at the Quirinal Palace (which is the official residence of the President of the Republic).

The photograph shows the two widows with Giorgio Napolitano, the President of Italian Republic, in 2009. In his presence they symbolically shook hands (Figure 2). The President of the Republic had strongly wanted this event, whose purpose was to restore dignity to Giuseppe Pinelli, the anarchist unjustly suspected of being involved in the attack in Piazza Fontana. Also Claudia Pinelli,

\footnotetext{
${ }^{10}$ Sixteen years later a Lotta Continua activist, Leonardo Marino, admitted that he had been one of the perpetrators and gave the names of his accomplice, Ovidio Bompressi, and the instigators, Giorgio Pietrostefani and Adriano Sofri, who, although they had always declared their innocence, were sentenced in 1997 to 22 years in prison after a long trial.
} 


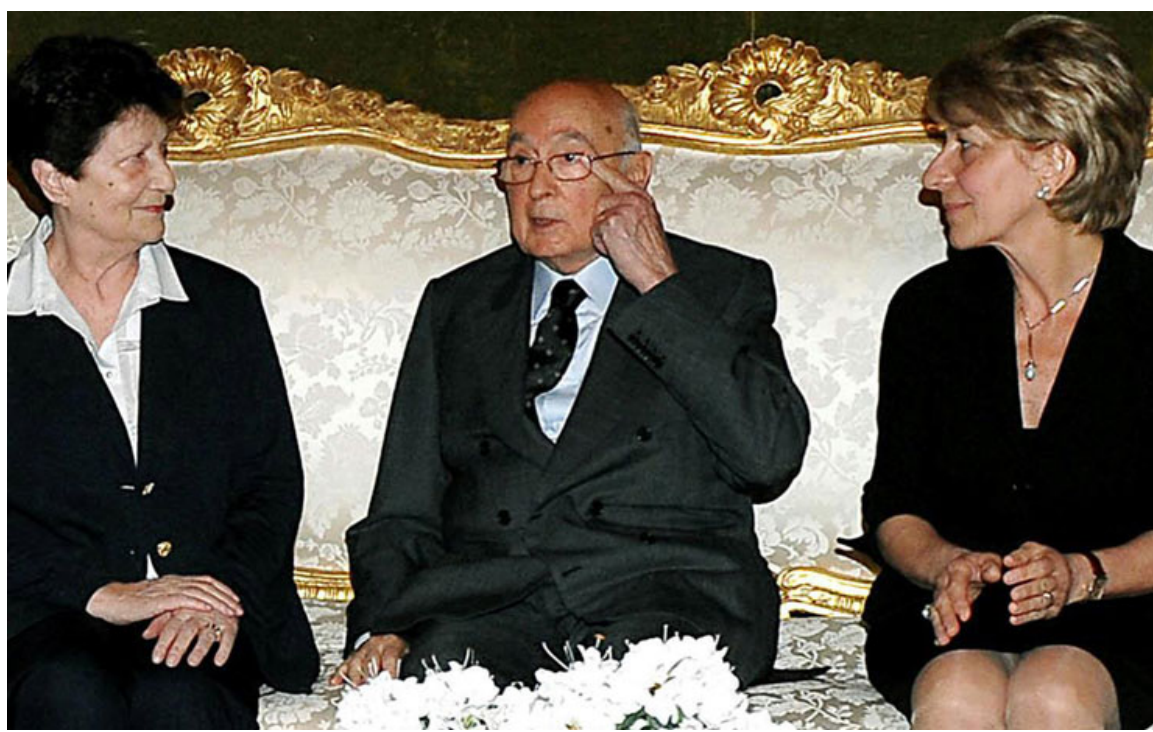

Figure 2. 9 May 2009, during the Commemorating Day of the Victims of Terrorism, Licia Rognini, Giuseppe Pinelli's widow, and Gemma Capra, the widow of the policeman Luigi Calabresi, at the Quirinal Palace in Rome with the President of the Republic, Giorgio Napolitano.

the daughter of Giuseppe Pinelli, and Luigi Calabresi's son, took part in the commemoration at the Quirinal Palace. This act of reconciliation was made possible by the institutional and personal efforts of the President of the Republic forty years after the event (1969-2009), and at the time of writing this article, that past is still subject to many controversies. Indeed, in 2016 the painting of Pinelli's Funeral produced by Enrico Bay in 1972 to commemorate the death of this innocent anarchist has not yet found a stable location. Bay was a well-known painter born in Milan who after Pinelli's murder decided to paint the famous canvas "Funeral of the anarchist Pinelli" (Figure 3). The painting was executed three years after Pinelli's death, but a few days before the official opening of the exhibition where the artwork was to be displayed, the police inspector Luigi Calabresi (considered "responsible" for Pinelli's death because he was the chief of police in Milan at that time) was killed. As a direct consequence, Enrico Bay's exhibition was immediately cancelled. As Foot (2002) [39] argues, for many years Milanese citizens witnessed a sort of symbolic war among different commemorative stones located in Pinelli's memory in piazza Fontana with different inscriptions recalling what happened ("dead", "killed", "murdered").

In the meantime Bay's painting was forgotten for decades. In 2012 it was displayed for the first time in an exhibition held at the Real Palace in "Piazza del Duomo" (a few meters' distance from the place where the bombing in 1969 occurred). The exhibition was a great success for several months. But when it ended, the painting was again forgotten, and in 2016 is still "homeless" in the sense that there is not yet a definitive place for its display in a permanent exhibition. Attempts are being made by the author of this article to resolve this situation and to find a possible location for the painting in a Milanese institution. 


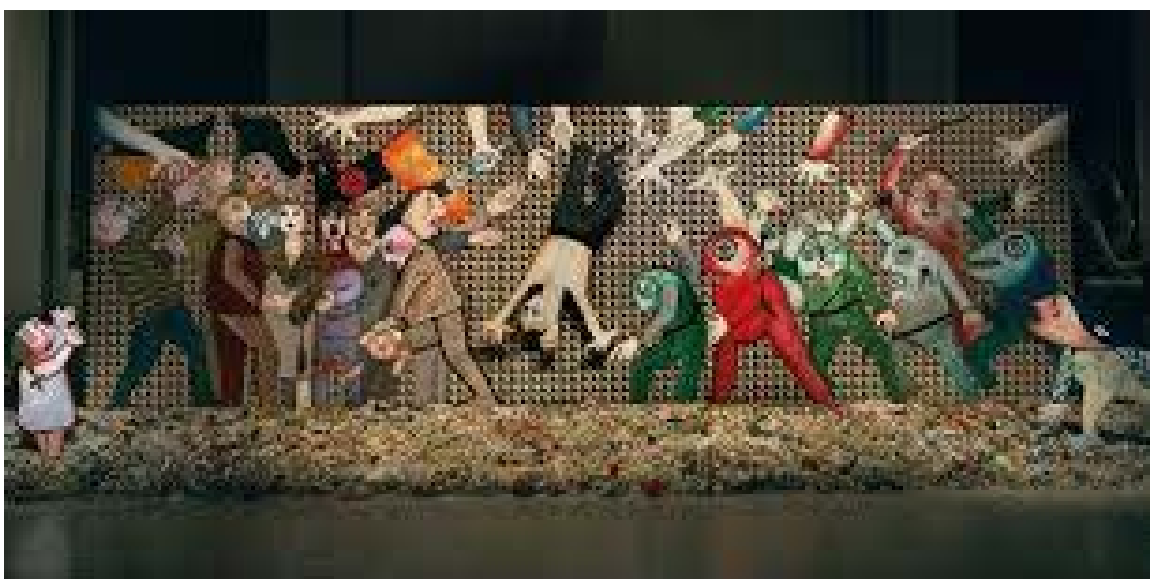

Figure 3. Enrico Bay's painting "Funerali dell'anarchico Pinelli" (1972).

Two international museums in Europe have already expressed to Pinelli's family their willingness to display the painting permanently; but of course it is a very important symbol for the public memory in Milan. That it should remain in Milan is generally agreed by Milanese citizens and Pinelli's relatives. Hence further negotiations with Milanese political and cultural institutions will be needed to find a stable destination for this very controversial artwork and a final solution seems to be still far away. The difficulties (almost fifty years after Pinelli's death) to find out a possible location for this painting represents an eloquent indicator of the degree of controversy still linked to this case. In Milan to expose this painting - the painting of a man, Giuseppe Pinelli, who died innocent and was therefore defined as the "eighteenth victim" of Piazza Fontana by the President Giorgio Napolitano-can still mean to "blame" Luigi Calabresi's reputation and to offend his relatives. If one does not consider the contemporaneity of the failed attempts to find a location for Enrico Baj's painting and the release of Giordana's movie one cannot really understand how courageous and important the Italian film director was.

How does Giordana's film contribute to illuminating the dilemmas linked to this case? Giordana's film is a very courageous one because at the outset it states the evidence that make the hypothesis of the involvement of international intelligence services very probable. At the end of the film, the inspector Luigi Calabresi, before he is murdered, discovers one of the secret depots of explosives and weapons in North Italy and is told that it belongs to NATO. The two lead characters of the film are Giuseppe Pinelli and Luigi Calabresi. Giordana has decided to depict both of them in their humanity, dignity, honesty and commitment to their ideals and values. At the end of the film, the spectator realises that they are both heroes and victims of the circumstances of that political time. The film lets Italian citizens understand the complexity of this past, the impossibility of synthesising it into any reductive and politicized account. It challenges the clichés about policemen, anarchists, terrorists, and suggests that alternatives are possible. This film enables Italian citizens recall this past without reducing it to 
one of its opposed and contrasting versions. Moreover, it suggests that the opacity of the strategy of tension, the impossibility of inscribing this recent period of the Italian past in the national public discourse with an official and shared acknowledgment of the perpetrators does not depend solely on Italian corruption; it also depends on the role of the international intelligence services in Italy. It discards the usual clichés of corrupt Italian citizens without moral dignity, dedicated to conspiracy and intrigue. It instead suggests that in Italy during those years an invisible war was being fought: the "Cold War". Therefore Italy's destiny was not decided by Italian politics alone, but also by other countries interested in limiting the spread of communist and leftist values in Europe. More than corrupt and unethical, Italians are portrayed in the film as the victims of a war fought in Italy in an apparent period of peace and whose victims were mainly Italian civilians who had nothing to do with terrorism, the Cold War and even the so-called threat of "communism". Moreover, the filmmaker Marco Tullio Giordana proposes here the "doppia bomba" thesis that made the film so controversial:

"(...) the film is an adaptation of a controversial book that argued that there were, in fact, two bombs planted in the bank: one by anarchists, intended to explode at night without victims, and the second by neofascists, facilitated by secret service operatives who had infiltrated both sets of groups, intended to explode in the busy afternoon with maximum cost to human life. This version of events is considered bizarre by many in Italy, where the widespread conviction is that there was a single, neofascist, bomb, but it explains the English title given to the film: Piazza Fontana: The Italian Conspiracy." (O’Leary, 2013) [40].

Also Hajek (2015) [41] underlines the importance of this film in opening up again the debate on Piazza Fontana, but she suggests that probably all the controversies and the open questions will be forgotten very soon again, as usually happens in Italy.

However, it is here suggested that this film has contributed to construct a counter memory (Foucault, 1977) [42] in the Italian public discourse in relation to the "strategy of tension" period, as it has challenged the official version of this past created and imposed by political institutions. As Foucault clearly explained, counter memories do challenge the established "memory". This movie clearly suggests that the strategy of tension was linked to the international context and it was due to the interference of the international intelligence services in the Italian society.

As a memory scholar who was born and lives in Milan, when I first saw this film, I thought that it has made possible a way in which to better understand this very contested past in Italy, a past that had divided and still divides the city of Milan. In 1969 I was only four years old, and I could not really grasp what was going on in Italy during those terrible years. Not even in their families did members of my generation find support or information helping them to comprehend that past properly. The strategy of tension was neglected, and it was not inscribed in the public discourse for long. Pasolini made one of the first attempts 
to publicly denounce the effects of the Cold War in Italy. But his courageous denunciation probably cost him his life.

The aesthetic forms of this past have made alternative understandings of what happened accessible. I felt very grateful to this courageous filmmaker who was strongly criticised when the film was first released. Films like this one contribute to the democratic life of Italian society, offering new opportunities for all Italians to reconcile themselves to this very obscure period of their recent past.

\section{Conclusion: Aesthetic Truth and Public Memory in Post-War Italy}

In this article, I have tried to document the reasons why and the extent to which the Italian public memory of the strategy of tension period has undergone a process of aestheticising. I have illustrated the importance of recognising the role of the arts (and in this case especially of the cinema) in making alternative understandings of a difficult past possible, without claiming to resolve any of the dilemmas involved. It has been argued that film is exemplary as a site of revealing truth, making mourning and reconciliation, as well as potential political change possible. However, some concluding remarks are required also in relation to the specificity of the Italian case. In Italy, the role of the arts in performing the trauma process for very difficult pasts is necessarily amplified by the lack of functioning legal and institutional arenas. In several cases, trials have been stopped and judges killed to prevent them from investigating further. Therefore Italian citizens gain their knowledge of the recent past mainly from films, theatrical performances, and exhibitions, as shown in the case of Romanzo di una strage, the film about the Piazza Fontana bombing directed by Marco Tullio Giordana in 2012. To understand past events in their country, Italians must go to the theatre, museums or the cinema. However, in the end, they have "only" been to the theatre or at the cinema. Put otherwise, public knowledge of this particular past has been produced through the aesthetic mode of production. It is here argued also that the history of its existence as "knowledge without proof" articulated and shared have made room for more criticism and articulation in art as well as other realms of cultural production. This public knowledge has a "degree of truth" not comparable, for example, with that of traditional historical or political discourse. In the end, citizens will be induced to think that "perhaps it tells the truth, but it is only a film". Thus reaffirmed is a type of "conspiracy narrative" in regard to those traumas: plausible, yet the degree of reality produced through aesthetic codes is insufficient to compete with other narratives in the nation's public discourse. However, commemorative rituals in Italy are opportunities for civil and political society to contribute to the values of democracy. They are also significant for the hegemony process, in that they make democracy possible.

\section{References}

[1] Alexander, J. (2004) Toward a Theory of Cultural Trauma. In: Alexander, J.C., 
Eyerman, R., Giesen, B., Smelser, N.J. and Sztompka, P., Eds., Cultural Trauma and Collective Identity, University of California Press, Berkeley, 1-30. https://doi.org/10.1525/california/9780520235946.003.0001

[2] Tota, A.L. (2003) La città ferita. Memoria e comunicazione pubblica della strage di Bologna, 2 agosto 1980. il Mulino, Bologna.

[3] Tota, A.L. (2005) Counter-Memories of Terrorism: The Public Inscription of a Dramatic Past. In: Jacobs, M. and Hanharan, N., Eds., Blackwell Companion to the Sociology of Culture, Blackwell, Oxford, 272-285. https://doi.org/10.1002/9780470996744.ch18

[4] Tota, A.L. (2005) Terrorism and Collective Memories: Comparing Bologna, Naples and Madrid March 11. International Journal of Comparative Sociology, 46, 55-78. https://doi.org/10.1177/0020715205054470

[5] Wagner-Pacifici, R. (1986) The Moro Morality Play. Terrorism as Social Drama, The University of Chicago Press, Chicago.

[6] Dickie, J., Foot, J. and Snowden, M. (2002) Disastro! Disasters in Italy since 1860: Culture, Politics and Society. Palgrave, New York.

[7] Tranfaglia, N. (2010) Anatomia dell'Italia repubblicana. 1943-2009, Passigli, Bagno a Ripoli. Firenze.

[8] Tranfaglia, N. (2011a) La "santissima trinità". Mafia, Vaticano e servizi segreti all'assalto dell'Italia 1943-1947, Bompiani, Milano.

[9] Tranfaglia, N. (2011b) Più di cento anni ma la mafia c'è sempre. Crisi della Repubblica e ascesa delle mafie (1861-2011). Edizioni dell'Orso, Alessandria.

[10] Galfrè, M. (2014) La Guerra é finita. L’Italia è uscita dal terrorismo 1980-1987. Laterza, Bari.

[11] Alexander, J.C., Eyerman, R., Giesen, B., Smelser, N.J. and Sztompka, P. (2004) Cultural Trauma and Collective Identity. University of California Press, Berkeley. https://doi.org/10.1525/california/9780520235946.001.0001

[12] Wagner-Pacifici, R. (2010) Theorizing the Restlessness of Events. American Journal of Sociology, 115, 1351-1386. https://doi.org/10.1086/651299

[13] Wagner-Pacifici, R. (2016) Reconceptualizing Memory as Event: From "Difficult Pasts" to "Restless Events". In: Tota, A.L. and Hagen, T., Eds., Routledge International Handbook of Memory Studies, Routledge, London, 22-27.

[14] Olick, J.K. (2014) Willy Brandt in Warsaw: Event or Image? History or Memory? In: Shevchenko, O., Ed., Double Exposure: Memory and Photography, Transaction Press, New Brunswick and London, 21-40.

[15] Halbwachs, M. (1950) La mémoire collective. PUF, Paris.

[16] Rubin, M. (2002) What Is Cultural History Now? In: Cannadine, D., Ed., What Is History Now? Palgrave, London, 80-94. https://doi.org/10.1057/9780230204522_5

[17] Tota, A.L. and Hagen, T. (2016) Routledge International Handbook of Memory Studies. Routledge, London.

[18] Olick, J.K., Vinitzky-Seroussi, V. and Levy, D. (2011) The Collective Memory Reader. Oxford University Press, Oxford.

[19] Dorter, K. (1990) Conceptual Truth and Aesthetic Truth. The Journal of Aesthetics and Art Criticism, 48, 37-52. https://doi.org/10.2307/431198

[20] Wagner-Pacifici, R. and Schwartz, B. (1991) The Vietnam Veterans Memorial: Commemorating a Difficult Past. American Journal of Sociology, 97, 376-420. https://doi.org/10.1086/229783 
[21] Wagner-Pacifici, R. (1996) Memories in the Making: The Shapes of Things That Went. Qualitative Sociology, Special Issue on Collective Memory, 19, 301-321. https://doi.org/10.1007/BF02393274

[22] Eyerman, R. (2002) Cultural Trauma. Slavery and the Formation of African American Identity. Cambridge University Press, Cambridge.

[23] Alexander, J. (2012) Trauma: A Social Theory. Polity Press, London.

[24] Goldfarb, J. (2016), Memory, Art and the Social Condition. European Journal of Cultural and Political Sociology, Special Issue on Claims to Truth: Authenticity in Aesthetic Paths to Justice and Public Memory, 4, 282-305.

[25] O’Leary, A. (2011) Tragedia all'italiana: Italian Cinema and Italian Terrorism, 1970-2010. Peter Lang, Oxford. https://doi.org/10.3726/978-3-0353-0106-9

[26] Glynn, R.S., Lombardi, G. and O’Leary, A. (2012) Terrorism, Italian Style: Representations of Political Violence in Contemporary Italian Cinema. IGRS Books, London.

[27] Hajek, A. (2013) Negotiating Memories of Protest in Western Europe. The Case of Italy. Palgrave Macmillan, New York. https://doi.org/10.1057/9781137263780

[28] Antonello, P. and O'Leary, A. (2009) Introduction. In: Antonello, P. and O'Leary, A., Eds., Imagining Terrorism. The Rethoric and the Representation of Political Violence in Italy 1969-2009, Legenda, London, 1-15.

[29] O'Leary, A. (2010) Italian Cinema and the "anni di piombo". Journal of European Studies, 40, 243-257. https://doi.org/10.1177/0047244110371912

[30] Pasolini, P.P. (1974) What Is This Coup? I Know. Corriere della Sera, Milan, November 14 .

[31] Arendt, H. (1963/1992) Eichmann in Jerusalem: A Report on the Banality of Evil. Penguin, Hardmondsworth.

[32] Rensmann, L. (2015) Reading Arendt in Teheran: On Extraordinary Democratic Politics and the Failure of Revolutions. European Journal of Cultural and Political Sociology, 1, 299-315. https://doi.org/10.1080/23254823.2014.992116

[33] Ganser, D. (2005) NATO's Secret Armies: Operation GLADIO and Terrorism in Western Europe. Frank Cass Publishers, London.

[34] Colby, W. and Forbath, P. (1978) Honorable Men: My Life in the CIA. Simon \& Schuster, New York.

[35] Commissione parlamentare d'inchiesta sul terrorismo in Italia e sulle cause della mancata individuazione dei responsabili delle stragi (1997) L'Italia delle stragi: Da Portella della Ginestra alla strategia della tensione nella relazione della Commissione Stragi. Vol. 1, F. Rizzi (Ed.), il Minotauro, Milano.

[36] Rosenstone, R. (2014) History on Film/Film on History. Routledge, New York \& London.

[37] Rosenstone, R. (1995) The Historical Film as Real History. Film-Historia, 1, 5-23.

[38] Tota, A.L. (2010) Narrating the Shoah: From Maus to Life Is Beautiful. In: Schenk, I., Tröhler, M. and Zimmermann, Y., Eds., Kino, Film Zuschauer, Filmrezeption, Schüren, Marburg, 339-353.

[39] Foot, J. (2002) The Disaster and the City. Milan and Piazza Fontana, 1969-1999. In: Dickie, J., Foot, J. and Snowden, F., Eds., Disastro! Disasters in Italy since 1860: Culture, Politics and Society, Palgrave, New York, 256-281.

[40] O’Leary, A. (2013).

http://italiancinema-mumbai.tumblr.com/post/58502045763/introduction-to-roma nzo-di-una-strage 
[41] Hajek, A. (2015) L' “io so” di Marco Tullio Giordana: La strage di Piazza Fontana al cinema.

https://centrotrame.wordpress.com/2012/04/05/lio-so-di-marco-tullio-giordana-lastrage-di-piazza-fontana-al-cinema-43-anni-dopo/

[42] Foucault, M. (1977) Language, Counter-Memory, Practice. Cornell University Press, Ithaca.

[43] Antonello, P. (2012) Dimenticare Pasolini. Mimesis, Milano.

[44] Gordon, R. (2007) Pasolini's Murder: Interpretations, Event Narratives, and Postmodern Impegno. In: Gundle, S. and Rinaldi, L., Eds., Assassinations and Murders in Modern Italy, Palgrave, New York, 153-165.

https://doi.org/10.1057/9780230606913_13

[45] White, H. (1973) Metahistory: The Historical Imagination in Nineteenth-Century Europe. The Johns Hopkins University Press, Baltimore.

[46] Antonello, P. and O'Leary, A. (2009) Imagining Terrorism: The Rhetoric and Representation of Political Violence in Italy, 1969-2006. Legenda, London.

[47] Luchetti, L. and Tota, A.L. (2016) An "Unaccomplished Memory": The Period of the "Strategy of Tension" in Italy (1969-1993) and the Piazza Fontana Bombing in Milan. In: Tota, A.L. and Hagen, T., Eds., Routledge International Handbook of Memory Studies, Routledge, London, 382-397.

[48] Imposimato, F. (2012) La Repubblica delle stragi impunite. Newton Compton, Roma.

[49] Foot, J. (2009) Italy's Divided Country. Palgrave, New York. https://doi.org/10.1057/9780230101838

[50] Luchetti, L. (2013) Piazza Fontana 12 dicembre 69: La memoria pubblica della strage. PhD Dissertation, University La Sapienza, Rome. 